\title{
Analisa Usabilitas Sistem Deteksi Akses Pornografi Pengguna Internet Menggunakan Metode Mccall'S
}

\author{
Bambang Sugiantoro $^{1}$, M. Mustakim ${ }^{2}$ \\ ${ }^{1,2}$ Teknik Informatika UIN Sunan Kalijaga Yogyakarta \\ ${ }^{1}$ bambang Sugiantoro@uin-suka.ac.id
}

\begin{abstract}
Saat ini sudah ada beberapa cara yang biasanya digunakan untuk mencegah pornografi, yang paling umum dengan metode keyword seperti nawala project yang menggunakan DNS filtering dan metode berbasis image. Metode ini mempunyai kelemahan karena bisa jadi seorang peneliti atau dosen fakultas sains dan teknologi ketika memerlukan sebuah informasi berkaitan dengan "sex" misalnya maka otomatis dia tidak bisa mengaksesnya. Bahkan saat ini para pembuat situs pornografi sudah begitu cerdas, memberikan nama situsnya dengan nama yang tidak ada hubunganya sama sekali dengan pornografi. Berdasarkan alasan diatas kami peneliti mengusulkan pengujian kualitas software dengan tema analisa usabilitas sistem deteksi akses pornografi pengguna internet menggunakan kualitas faktor usabiltas Mc Call's yang memadukan antara matrik operabilitas dan matrik training sebagai sarana untuk menentukan kualitas software.
\end{abstract}

Kata kunci-Usabiltas Mc Call's, matrik operabilitas, matrik training dan kualitas software

\section{PENDAhUluan}

Pengujian perangkat lunak merupakan elemen kritis dari jaminan kualitas perangkat lunak dan merepresentasikan kajian pokok dari spesifikasi, desain, dan pengkodean [15]. Pengujian perangkat lunak adalah suatu proses yang digunakan untuk mengidentifikasi ketepatan, kelengkapan dan mutu dari perangkat lunak. Untuk setiap pengujian yang dilakukan dibutuhkan tersedianya suatu ukuran kualitatif dengan menggunakan strategi dengan mengintegrasikan metode design test case perangkat lunak ke dalam sederetan langkah yang direncanakan dengan baik, dan hasilnya adalah konstruksi perangkat lunak yang berhasil.

\section{TINJAUAN PUSTAKA}

Kualitas software adalah aspek terpenting dalam pengembangan sebuah software. Seperti penelitian yang dilakukan Ariawan (2007) dengan judul "Penerapan Software Quality Assurance (SQA) Study kasus Indonesia". Penerapan Software Quality Assurance yang digunakan pada semua developer software seluruh Indonesia. Penelitian ini menggunakan basis web untuk mengumpulkan jawaban, dengan cara membuat kuisioner online. Penelitian ini menggunakan pertanyaan dengan checklist pertanyaan yang ada pada Software Quality Assurance. Sehingga pengumpulan data hanya dengan menganalisis seberapa besar menurut pengguna yang berada di seluruh indonesia berdasarkan kuesioner online dan untuk memvalidasi dengan kuesioner offline dengancara penyebaran dan wawancara langsung dingan pengguna[5].

Sedangkan referensi yang kedua berasal dari tesis milik Universitas Indonesia yang diteliti oleh (Dodick Zulaimi Sudirman, 2009) dengan judul "Penggalian, penerapan, penjaminan kualitas perangkat lunak pada perusahaan perangkat lunak". Study kasus Indonesia. Penelitian ini yang menggali berapa besar kualitas perangkat lunak pada perusahaan perangkat lunak di Indonesia. Lalu peneliti menerapkan dan mengaplikasian pada penjaminan mutu perangkat lunak yang di keluarkan oleh perusahaan perangkat lunak. Kegiatan penjaminan mutu pada aplikasi perangkat lunak sangat menentukan hasil aplikasi yang dibuat. Peneliti menggunakan teori Software Quality Shrine milik Daniel Galin . Refrensi yang ketiga yang dilakukan Penelitiannya oleh (Nur Annisa Tresnasari, 2012). Penerapan model penjaminan mutu yang dapat dilakukan dan diterapkan pada pengembang perangkat lunak bersekala kecil. Peneliti mengambil tempat study kasus pada Pusat Komputer dan Sistem Informasi UIN Sunan Kalijaga Yogyakarta. Peneliti menggunakan Metode Software Qualty Assurancedengan model penjaminan mutu pada sekala kecil. Penilaianya hanya pada proses pengembangan proyeknya.

Penelitian dilakukan oleh Aji (2014) dengan melakukan komparasi terhadap dua perangkat lunak yaitu Blackberry Messenger dan Whatsapp Messenger. Komparasi di lakukan pada faktor Efficiency. Penelitian ini menghasilkan kesimpulan bahwa pada faktor Execution Efficiency perlu adanya peningkatan dan pengembangan lagi, terutama pada aplikasi Blackberry Messanger serta perbaikan pada faktor Operability [3].

Penelitian dilakukan dengan pengujian pada dua perangkat lunak KeePass Password Safe 1.10 dan PDF Split and Merge 2.1.0. Penelitian dilakukan dengan fokus pada pengujian faktor Corectness dan Usability. Penelitian ini memaparkan hasil bahwa pada perangkat lunak KeePass Password Safe 1.10 nilai matrik Corectness sebesar 96,2 \% dan matrik Usability sebesar 77,8\%, sedangkan pada perangkat lunak PDF Split and Merge 2.1.0 nilai matrik Corectness sebesar 93,3\% dan matrik Usability sebesar 82,6\% [9].

Fararit (2015) melakukan penelitian terhadap Sistem Informasi Alumni UIN Sunan Kalijaga Yogyakarta. Pengujian ini dilakukan dengan fokus terhadap faktor Corectness dan Usability. Penelitian ini memaparkan hasil nilai pada faktor correctness sebesar $95,23 \%$, dimana 
completeness sebesar 85,71\%, consistency $100 \%$ dan traceability $100 \%$, sedangkan faktor usability adalah operability sebesar 70,57\% $\pm 16,08 \%$ dan training sebesar 149,5666 $\pm 38,9114$ detik [7].

Penelitian dilaksanakan dengan melakukan pengujian terhadap pengujian terhadap faktor corectness dan usability pada Sistem Informasi Kepegawaian pada UIN Sunan Kalijaga Yogyakarta. Hasil dari penelitian ini dipaparkan bahwa pada matrik completeness di dapatkan hasil $100 \%$, matrik operability sebesar 73,66 \% $\pm 16,74$ $\%$, dan matrik training sebesar $45.98 \% \pm 15,23556$ detik. [11].

Syafirah (2015) melakukan pengujian terhadap Sistem Informasi Surat UIN Sunan Kalijaga. Penelitian dilakukan dengan berfokus pada pengujian faktor Reliability. Penelitian ini memaparkan hasil bahwa tingkat Reliabilitas yang dimiliki sistem tersebut adalah $85,11 \%$, yang diperoleh dari penghitungan nilai Accuracy $100 \%$, Error Tolerance $28 \%$, Consistency 97,53\%, Modularity $100 \%$, dan Simplicity $100 \%$ [19].

Penelitian lain dilakukan dengan melakukan pengujian pada Sistem Portal Web Pondok Pesantren Ibnul Qoyyim Yogyakarta. Penelitian ini dilakukan dengan fokus pada pengujian faktor Usability. Penelitian ini memaparkan hasil nilai matrik Operability $70.51 \% \pm 11.42 \%$ dan matrik Training 22 detik \pm 17.1 detik [20]

Yunitasari (2015) melakukan pengujian terhadap Sistem E-Learning UIN Sunan Kalijaga Yogyakarta. Penelitian ini dilakuka dengan fokus pengujian pada faktor Corectness dan Usability. Penelitian ini memaparkan hasil bahwa nilai correctness sebesar 95,23 $\%$, dimana completeness sebesar $85,71 \%$, consistency $100 \%$ dan traceability $100 \%$, sedangkan faktor usability adalah operability sebesar 70,57 \% $\pm 16,08 \%$ dan training sebesar 149,5666 $\pm 38,9114$ detik [22]

\section{METODE PENELITIAN}

Penelitian ini bertujuan untuk mengetahui nilai persentase kelayakan dari sistem deteksi pornografi dengan melakukan analisis berdasarkan standarisasi SQA (Software Quality Assurance) serta mengukur setiap parameter yang akan dianalisis.

Kerangka Penelitian ini di buat untuk memaparkan desain penelitian lengkap dengan pola analisisnya dan pengumpulan data yang digunakan untuk mendukung penelitian ini. Oleh karena itu kerangka penelitian yang di buat bersifat deskriptif, menjelaskan bagian yang akan di uji. Dalam hal ini peneliti membuat kerangka penelitian dalam bentuk tabel aktifitas pengujian agar memudahkan dalam pengumpulan data dan pendataan hasil penelitian yang dilakukan.

Penelitian deskriptif mempunyai langkah-langkah dalam pelaksanaannya, diantaranya: dimulai dengan adanya masalah, menentukan informasi yang diperlukan, mendeskripsikan prosedur pengumpulan data, mengolah data atau informasi, dan menarik kesimpulan dari penelitian yang dilakukan. Tahapan ini juga digunakan sebagai kerangka kerja dalam pengujian perangkat lunak

\section{Pengumpulan Data}

Pengumpulan data ini bertujuan untuk mendapatkan informasi dan fakta mengenai perangkat lunak yang di uji kemudian selanjutnya nanti jika data sudah terkumpul akan dianalisis menggunakan standar kualitas McCall. Pengumpulan data ini dapat dilakukan dengan beberapa cara, antara lain:

\section{Studi Literatur}

Studi literatur berguna sebagai pembelajaran teori untuk penelitian yang sedang dilaksanakan peneliti karena hal tersebut untuk melandasi pengujian dan analisis yang akan dilaksanakan. Peneliti mengambil dari buku, jurnal, skripsi serta artikel yang berhubungan dengan tema yang peneliti ambil sebagai landasan untuk analisis dan pengujian yang dilakukan. Sehingga diharapkan nantinya dapat membantu peneliti tentang teknik dan strategi dalam melaksanakan penelitian.

\section{Data Sistem}

Data sistem ini di ambil untuk digunakan sebagai bahan analisis secara sistematis. Data sistem ini diperoleh dari pengujian secara whitebox menggunakan modulmodul source code.

\section{Kuisioner}

Kuisioner ini digunakan untuk pengumpulan data yang kemudian digunakan untuk menghitung matrik Operability. Kuisioner ini disebarkan kepada responden pengguna dari sistem atau responden yang setidaknya pernah menggunakan Deteksi pornografi ini. Sebelum di sebarkan, terlebih dahulu kuisioner ini akan dilakukan pengujian validitas dan reliabilitasnya, setelah dipastikan bahwa item kuisioner ini valid dan reliabel kemudian barulah kuisioner ini di sebarkan untuk pengumpulan data.

\section{Metode Penghitungan}

1. Correctness

Matrik Correctness ini terdapat tiga faktor yang meliputi pengujian kebenaran, matrik itu adalah Completeness, Consistency, dan Tracebillity. Nilai Correctness di dapat dengan rumus:

Correctness $=\frac{\text { Completeness }+ \text { Consistency }+ \text { Tracebility }}{3}$

\section{Reliability}

Matrik reliabilitas ini memiliki lima faktor pengujian yaitu: Accuracy, Consistency, Error Tolerance, Modularity, dan Simplicity. Nilai presentase reliabilitas di dapat dengan rumus:

Reliability $=$

Accuracy + ErrorTolerance + Consistency + Modularity + Simplicity

\section{Efficiency}

Matrik Efficiency ini memiliki tiga faktor di dalamnya, yaitu: Conciseness, Execuition Efficiency, dan Operability. Nilai Efficiency di dapat denga rumus: 
Efficiency $=\frac{\text { Conciseness }+ \text { Execution Efficiency }+ \text { Operability }}{3}$

\section{Integrity}

Matrik Integrity ini memiliki tiga faktor di dalamnya, yaitu: Auditability, Instrumentation, dan Security. Nilai Integrity di dapatkan dengan rumus:

Integrity $=\frac{\text { Auditability+Instrumentation }+ \text { Security }}{3}$

5. Usability

Matrik Usability ini hanya memiliki dua faktor di dalamnya, yaitu: Training dan Operability. Nilai Usability di dapatkan dengan rumus:

$$
\text { Usability }=\frac{\text { Training }+ \text { Operability }}{2}
$$

\section{Analisis Data}

Tahap selanjutnya setelah peneliti mendapatkan data yang dibutuhkan adalah menganalisis data sesuai dengan standar kualitas $\mathrm{McC}$ all. Pengolahan dan penganalisisan data primer ini meliputi semua aspek dari product operation teori kualitas McCall. Analisis ini dilakukan pada setiap faktor yang ada untuk menentukan hasil dan mencari kesimpulan apakah sistem ini sudah memenuhi standar kualitas yang baik menurut teori kualitas $\mathrm{McC}$ Call.

\section{PEMBAHASAN}

Deteksi pornografi Pengguna Internet di browser dengan menggunakan teori McCall's Software Quality Factor.Pengujian yang dilakukan dengan parameter pengujian berdasarkan Product Operation McCall mencakup lima matrik antara lain: Correctness, Reliability, Efficiency, Integrity, dan Usability.

\section{A. Correctness}

Pengujian matrik Correctness adalah sejauh mana suatu software memenuhi spesifikasi dan mission objective dari users. Dalam matrik Correctness ini terdapat tiga faktor pengujian yaitu: Completeness, Tracebility, dan Consistency.

\section{1) Completeness}

Completeness adalah sejauh mana implementasi penuh dan fungsi-fungsi yang diperlukan telah tercapai. Berikut ringkasan hasil pengujian Completeness pada sistem Deteksi pornografi.

Completeness:

$$
\text { Completeness }=\frac{1}{4} \times 100 \%
$$

Dari hasil pengujian yang di dapatkan diatas dapat peneliti simpulkan bahwa sistem Deteksi pornografi ini memiliki nilai kelengkapan yang cukup.

\section{2) Tracebility}

Tracebility adalah kemudahan merujuk balik implementasi atau komponen program ke kebutuhan pengguna software. Berikut ringkasan hasil pengujian faktor Tracebility pada sistem Deteksi pornografi yang telah peneliti lakukan.

Dari pengujian faktor Tracebility peneliti memperoleh hasil bahwa pengujian dilakukan terhadap 70 menu. Total remark kesesuaian antara produk atau sistem dengan dokumen analisis yang di dapat dari pengujian adalah 70 menu. Berikut presentase pengujian untuk faktor Tracebility:

$$
\text { Tracebility }=\frac{4}{4} \times 100 \%
$$

$$
=100 \%
$$

Berdasarkan hasil yang di dapatkan dapat peneliti simpulkan bahwa sistem Deteksi pornografi ini memiliki nilai kesesuaian yang sangat baik antara sistem dengan dokumen analisis.

\section{3) Consistency}

Consistency adalah derajat penggunaan teknikteknik desain dan dokumentasi yang seragam pada seluruh proyek pengembangan software. Berikut ringkasan hasil pengujian faktor Consistency.

Dari pengujian faktor Consistency peneliti memperoleh hasil bahwa pengujian dilakukan terhadap 4 menu. Total remark kesesuaian atara dokumen analisis dengan sistem yang di dapat dari pengujian adalah 4 menu. Berikut presentase pengujian untuk faktor Consistency:

$$
\text { Consistency }=\frac{4}{4} \times 100 \%
$$

$$
=100 \%
$$

Hasil tersebut menujukkan bahwa sistem Deteksi pornografi memiliki nilai konsistensi yang sangat baik, antara dokumen analisis denga sistemnya.

Berdasarkan hasil pengujian yang di dapat dari ketiga faktor, maka presentase akhir pengujian matrik Correctness adalah sebagai berikut:

$$
\begin{gathered}
\text { Correctness } \\
\text { Completeness }+ \text { Tracebility }+ \text { Consistency } \\
=\frac{25 \%+100 \%+100 \%}{3}
\end{gathered}
$$

Dapat ditarik kesimpulan bahwa nilai kebenaran sistem Deteksi pornografi ini cukup baik.

\section{B. Reliability}

Pengujian matrik Reliability adalah sejauh mana suatu software dapat diharapkan untuk melaksanakan fungsinya dengan ketelitian yang diperlukan. Dalam matrik Reliability ini terdapat lima faktor pengujian, yaitu: Accuracy, Consistency, Error Tolerance, Modularity, dan Simplicity.

\section{1) Accuracy}

Accuracy adalah pengujian yang dilakukan untuk menentukan nilai ketelitian pada komputasi program dan control. Berikut ringkasan hasil pengujian faktor Accuracy, 
Dari pengujian faktor Accuracy, peneliti memperoleh hasil bahwa pengujian dilakukan terhadap menu. Total remark keakuratan antara input dengan output yang di dapat dari pengujian Berikut presentase pengujian untuk faktor Accuracy:

$$
\text { Accuracy }=\frac{3276}{4010} \times 100 \%
$$$$
=81.6 \%
$$

Peneliti mengambil kesimpulan dari hasil tersebut menunjukkan bahwa keakuratan yang dimiliki oleh sistem Deteksi pornografi ini baik.

\section{2) Consistency}

Pengujian faktor Consistency ini sama seperti yang telah di paparkan dalam pengujian matrik Correctness sebelumnya, maka peneliti tidak perlu menjabarkan kembali. Hasil dari pengujian faktor Consistency ini adalah:

$$
\begin{aligned}
\text { Consistency }=\frac{4}{4} \times 100 \% & \\
& =100 \%
\end{aligned}
$$

Yang menunjukkan bahwa sistem Deteksi pornografi ini memiliki konsistensi yang sangat baik antara dokumen analisis dengan sistemnya.

\section{3) Error Tolerance}

Error Tolerance adalah pengujian yang dilakukan untuk menentukan nilai toleransi terhadap kesalahan yang terjadipada program. Berikut rangkuman hasil pengujian faktor Error tolerance,

Dari pengujian faktor Error Tolerance, peneliti memperoleh hasil bahwa pengujian dilakukan .Berikut presentase pengujian untuk faktor Error Tolerance:

$$
\begin{aligned}
\text { Error Tolerance }= & \frac{734}{4010} \times 100 \% \\
& =18.3 \%
\end{aligned}
$$

Hasil tersebut menunjukkan bahwa sistem Deteksi pornografi ini masih buruk dalam toleransi terhadap kesalahan yang terjadi selama penggunaan.

\section{4) Modularity}

Modularity adalah pengujian ini dilakukan untuk menentukan nilai seberapa independen atau mandirinya sebuah modul yang menjadi komponen sebuah software. pengujian ini dilakukan untuk menentukan nilai seberapa independen atau mandirinya sebuah modul yang menjadi komponen sebuah software. Berikut ringkasan hasil pengujian faktor Modularity,

Dari pengujian faktor Modularity, peneliti memperoleh hasil bahwa pengujian dilakukan terhadap 5 class, total remark class yang independent adalah 2 class, dan class yang dependent adalah 3 class. Berikut presentase pengujian untuk faktor Modularity:

$$
\text { Modularity }=\frac{2}{5} \times 100 \%
$$

$$
=40 \%
$$

Berdasarkan hasil tersebut dapat peneliti simpulkan bahwa sistem Deteksi pornografi ini memiliki nilai kemandirian modul yang belum baik.

\section{5) Simplicity}

Simplicity adalah pengujian kesederhanaan pada penggunaan source code yang mengacu pada berapa banyak jumlah dipanggilnya sebuah modul yang apabila semakin besar atau sama dengan jumlah memanggilnya sebuah modul tersebut maka semakin mudah dipahami (simple). Berikut ringkasan hasil pengujian faktor Simplicity

Total Class yang Diuji :

Remark Simple : : 1

Remark Not Simple : : 4

Dari pengujian faktor Simplicity, peneliti memperoleh hasil bahwa pengujian dilakukan terhadap 56 class, dan total class yang simple adalah 5 class. Berikut presentase pengujian untuk faktor Simplicity:

$$
\text { Simplicity }=\frac{1}{5} \times 100 \%
$$

Hasil pengujian tersebut menunjukkan bahwa tingkat kesederhanaan penggunaan sorce code pada sistem Deteksi pornografi ini masih rendah.

Berdasarkan hasil pengujian yang di dapat dari kelima faktor tersebut, maka presentase akhir dari pengujian matrik Reliability ini adalah:

Reliability $=\frac{\text { Accuracy }+ \text { Consistency }+ \text { ErrorTolerance }+ \text { Modularity }+ \text { Simplicity }}{5}$

$$
\text { Reliability }=\frac{81,6 \%+100 \%+18,3+40 \%+20 \%}{5}=51.98 \%
$$

Peneliti mengambil kesimpulan dari hasil penelitian tersebut bahwa nilai reliabilitas sistem Deteksi pornografi masih tergolong kurang baik, hal tersebut dapat dilihat dari hasil presentase keseluruhan yang masih di bawah $60 \%$.

\section{Efficiency}

Pengujian matrik Efficiency adalah banyaknya sumber daya komputasi dan kode program yang dibutuhkan suatu software untuk melakukan fungsinya. Dalam matrik Efficiency ini terdapat tiga faktor pengujian yaitu: Conciseness, Execution Efficiency, dan Operability.

\section{1) Conciseness}

Conciseness adalah pengujian dengan cara menghitung keringkasan dan kepadatan program dalam jumlah baris kodenya. Berikut ringkasan hasil pengujian faktor Conciseness,

$$
\begin{array}{lll}
\text { Total Class yang Diuji } & : & 5 \\
\text { Total Nilai Remark Class } & : & 0,1894
\end{array}
$$

Dari pengujian faktor Conciseness, peneliti memperoleh hasil bahwa pengujian dilakukan terhadap 56 class, dan total nilai remark class yang di dapatkan adalah 1188,97. Berikut presentase pengujian untuk faktor Conciseness:

$$
\text { Conciseness }=\frac{5-0,1894}{5} \times 100 \%
$$

Berdasarkan presentase pengujian tersebut mengindikasikan bahwa rata-rata kepadatan baris kodenya adalah $62.12 \%$. 


\section{2) Execution Efficiency}

Execution Efficiency adalah pengujian dengan menghitung nilai keefisiensi program dari kinerja runtimenya saat digunakan pada device. Penghitungan kinerja run-time meliputi memori yang digunakan saat sudah dipasang, sampai pengguna memori (RAM) saat program tersebut berjalan.

Berikut perkiraan peneliti untuk faktor Conciseness pada browser Mozilla Firefox:

$$
\text { Execution Efficiency }=90 \%
$$

\section{3) Operability}

Operability adalah pengujian dari kemudahan pengguna/pengoprasian program. Dalam tahap operability ini mempergunakan angket/kuisioner yang diberikan pada pengguna sistem atau setidaknya orang yang pernah menggunakan sistem. Pengambilan data pada kuisioner ini keseluruhan pengguna memberikan penilaian terhadap sistem Deteksi pornografi. Berikut adalah hasil pengujian faktor Operability

Berikut perkiraan presentase untuk faktor Operability:

$$
\text { Operability }=80 \%
$$

Kesimpulan dari hasil pengujian tersebut adalah bahwa nilai kepuasan pengguna terhadap sistem Deteksi pornografi ini adalah $80 \%$, yang berarti bahwa tingkat kepuasan penggunanya baik.

Berdasarkan hasil pengujian yang di dapat dari ketiga factor tersebut, maka presentase akhir dari matrik Efficiency ini adalah:

$$
=\frac{\text { Conciseness }+ \text { Execution Efficiency }+ \text { Operability }}{3}
$$

Hasil tersebut menunjukkan bahwa tingkat keefisienan sistem Deteksi pornografi ini secara keseluruhan sudah sangat baik dan tingkat kepuasan pengguna sistem ini juga sangat baik.

\section{Integrity}

Integrity adalah pengujian tentang sejauh mana akses ke software dan data oleh pihak yang tidak berhak dapat dikendalikan. Pada pengujian matrik Integrity ini terdapat tiga faktor prngujian, antara lain: Auditability, Instrumentation, dan Security.

\section{1) Auditability}

Auditability adalah penyesuaian/keselarasan terhadap standar yang dapat diperiksa. Auditabilitas merupakan pengujian software dengan cara melihat desain sistemnya.

Berikut perkiraan presentase untuk faktor Auditability:

$$
\text { Auditability }=100 \%
$$

Peneliti dapat menyimpulkan bahwa sistem Deteksi pornografi ini memiliki kesesuaian/keselarasan antara sistem dengan dokumen analisis.

\section{2) Instrumentation}

Instrumentation adalah tingkatan dimana pengawasan program memiliki operasi tersendiri dan mengidentifikasi kesalahan yang terjadi. Sehingga program dapat mengenal, mengidentifikasi dan menangani error yang terjadi. Berikut adalah Perkiraan faktor Instrumentation,

Berikut presentase pengujian untuk faktor Instrumentation:

Instrumentation $=90 \%$

Peneliti menyimpulkan bahwa sistem Deteksi pornografi memiliki batasan intrumen yang jelas atau baik.

\section{3) Security}

Security merupakan ketersediaan mekanisme yang mengontrol atau melindungi program atau data. Berikut adalah hasil pengujian faktor Security

Tabel 1. Hasil Pengujian faktor Security

\begin{tabular}{cccccc}
\hline No & Activity & $\begin{array}{c}\text { Doc } \\
\text { Analisis }\end{array}$ & Product & Remark & Note \\
\hline 1. & Login & $x$ & $x$ & $x$ & \\
2. & $\begin{array}{c}\text { Session } \\
\text { Logout } \\
\text { Level } \\
\text { User }\end{array}$ & $x$ & $x$ & $x$ & \\
3. & $x$ & $x$ & $x$ & \\
4. & $\begin{array}{c}\text { Enkripsi } \\
\text { Password }\end{array}$ & $x$ & $x$ & $x$ \\
\hline & & Total & & 0
\end{tabular}

Dari pengujian faktor Security peneliti memperoleh hasil bahwa pengujian dilakukan terhadap 5 item keamanan sistem. Total remark yang di dapat dari pengujian adalah 3 menu yang terdapat di dalam sistem Deteksi pornografi. Berikut presentase pengujian untuk faktor Security:

$$
\begin{array}{r}
\text { Security }=\frac{0}{4} \times 100 \%=0 \%
\end{array}
$$

Peneliti menyimpulkan bahwa sistem Deteksi pornografi ini memiliki standar keamanan yang sangat jelek

Berdasarkan pengujian yang telah dilakukan diatas, maka presentase total matrik Integrity yang di dapatkan adalah:

Integrity $=$ Auditability+Instrumentation+Security

$$
\begin{array}{r}
\text { Integrity }=\frac{100 \%+90 \%+0 \%}{3} \\
\text { Integrity }=63.3 \%
\end{array}
$$


Hasil pengujian tersebut menunjukkan bahwa hubungan antar sistem dan keamanan sistem Deteksi pornografi ini sudah baik.

\section{E. Usability}

Pengujian matrik Usability adalah usaha yang diperlukan untuk mempelajari, mengoperasikan, menyiapkan input, dan mengartikan output dari software. Dalam pengujian Usability ini terdapat dua faktor pengujian yaitu Operability dan Training.

\section{1) Operability}

Operability adalah pengujian dari kemudahan pengguna/pengoprasian program. Pada pengujian Operability ini telah di bahas dalam matrik Efficiency dan telah di jabarkan dalam matrik efficiency di depan maka peneliti tidak perlu menjabarkan lebih lanjut operability dengan nilai $80 \%$

Berdasarkan hasil tersebut peneliti dapar menyimpulkan bahwa tingkat kepuasan pengguna terhadap sistem Deteksi pornografi ini berada pada tingkat yang baik.

\section{2) Training}

Training adalah tingkatan dimana software membantu menerapkan system oleh user yang baru. Dari pengujian faktor Training responden diminta mencoba 6 aktifitas dalam sistem Deteksi pornografi kemudian setiap aktifitas tersebut di catat waktu penggunaanya. Berikut perkiraan pengujian untuk faktor Training: Training $=170,96$ detik

Berdasarkan asumsi pengujian ini menunjukkan bahwa pengguna membutuhkan waktu sekitar \pm 3 menit untuk memahami sistem Deteksi pornografi ini.

\section{F. Hasil Penelitian}

Pada tahap hasil penelitian ini peneliti akan memaparkan hasil penelitian yang telah peneliti lakukan. Berdasrkan parameter Product Operation teori kualitas McCall, terdapat lima matrik dengan enam belas faktor pengujian yang kesemuanya telah peneliti analisis dan melakukan asumsi pengujian terhadap data yang di dapatkan dari sistem Deteksi pornografi. Berikut adalah pemaparan hasil pengujian yang telah selesai peneliti lakukan.

\section{1) Correctness}

Berdasarkan hasil pengujian di atas di dapatkan hasil bahwa nilai Corectness atau kebenaran dari sistem Deteksi pornografi ini adalah sebesar: $75 \%$. Hasil tersebut di dapatkan dari perhitungan ketiga faktor yang terdapat di dalam matrik Corectness, yaitu: Completeness sebesar 25\%, Tracebility sebesar 100\%, dan Consistency sebesar 100\%. Dari hasil tersebut dapat ditarik kesimpulan bahwa sistem Deteksi pornografi ini memiliki nilai kebenaran yang cukup baik.

\section{2) Reliability}

Berdasarkan hasil pengujian yang telah peneliti lakukan, hasil yang di dapat untuk matrik Reliability adalah sebesar: 51,98\%. Hasil tersebut di dapat dengan akumulasi dari kelima faktor yang terdapat di dalam matrik Reliability, antara lain: Accuracy sebesar 81,6\%, Consistency sebesar 100\%, Error Tolerance sebesar 18,3\%, Modularity sebesar 40\%, dan Simplicity sebesar $20 \%$. Hasil ini menunjukkan bahwa pada matrik reliability ini nilai yang di dapatkan masih terbilang rendah.

Hasil dari pengujian matrik Reliability ini rendah karena berdasarkan pengujian yang peneliti lakukan validasi pada field-field di dalam tiga menu yang diuji masih sangat minim, menyebabkan nilai dari faktor error tolerance rendah. Sedangkan untuk faktor modularity dan simplicity hasil rendah.

\section{3) Efficiency}

Hasil yang peneliti dapatkan dari pengujian matrik Efficiency sistem Deteksi pornografi adalah sebesar: $77,3 \%$. Hasil tersebut di dapatkan dari akumulasi ketiga faktor yang ada di dalam Efficiency, yaitu: Conciseness 62.12\%, Execution Efficiency sebesar 90\%, dan Operability sebesar $80 \%$. Pada matrik Efficiency ini nilai yang di dapatkan sudah menunjukkan nilai yang sangat baik.

\section{4) Integrity}

Berdasarkan pengujian yang telah peneliti lakukan di atas, hasil yang di dapatkan pada matrik Integrity adalah: $63,3 \%$. Didapat dari akumulasi ketiga faktornya, yaitu: Auditability sebesar 100\%, Instrumentation sebesar 90\%, dan Security sebesar 0\%. Dari hasil tersebut dapat disimpulkan bahwa sistem ini memiliki memiliki relasi yang baik, namun sangat jelek pada faktor keamanannya.

\section{KESIMPULAN}

Berdasarkan penelitian yang telah peneliti lakukan, Peneliti dapat memberikan kesimpulan bahwa metode McCall dapat di terapkan untuk pengukuran kualitas perangkat lunak sistem deteksi pornografi Pengguna Internet di browser, Secara keseluruhan sistem Deteksi pornografi Pengguna Internet ini sudah memiliki kualitas yang baik berdasarkan teori kualitas McCall. Dari pengujian berdasarkan teori kualitas McCall ini yang memiliki kualitas terbaik adalah matrik usability dengan hasil sebesar $80 \%$ dan yang terburuk adalah matrik Reliability dengan hasil sebesar 51,98\%.

\section{ACKNOWLEDGMENT}

Lembaga penelitian dan pengabdian kepada masyarakat UIN Sunan Kalijaga Yogykarta 


\section{REFERENSI}

[1] - (2010). Sejarah SLiMS. Diakses dari http://slims.web.id/web/?q=node/70 pada tanggal 8 Oktober 2015.

[2]

(2012). Deteksi pornografi Pengguna Internet di browser (SLiMS). Diakses dari http://perpustakaan.kemdikbud.go.id/perpus/?page i $\mathrm{d}=224$ pada tanggal 8 Oktober 2015.

[3] Aji, D. M. (2014). Analisis Komparatif Faktor Efisiensi Pada Aplikasi Blackberry Messenger Berbasis Android Dengan Whatsapp Messenger Berbasis Android Berdasarkan Teori McCall's Quality Factors. Yogyakarta: Skripsi Teknik Informatika, UIN Sunan Kalijaga.

[4] Ardli, I. Z. (2015). Analisis Sistem Informasi Keuanga Desa di Kecamatan Wonosari Klaten Berdasarkan teori Kualitas McCall. Yogyakarta: Skripsi Teknik Informatika, UIN Sunan Kalijaga.

[5] Ariawan, Y. (2007). Penerapan Software Quality Assurance. Jakarta: UI Press.

[6] Arikunto, S. (2002). Metodologi Penelitian. Jakarta: PT Rineka Cipta.

[7] Fararit, F. M. (2015). Pengujian Faktor Corectness dan Usability Sistem Informasi Alumni UIN Sunan Kalijaga Yogyakarta Menggunakan Metode McCall. Yogyakarta: Skripsi Teknik Informatika, UIN Sunan Kalijaga.

[8] Gunawan, T. (2015). Pengujian Perangkat Lunak Deteksi pornografi Pengguna Internet di browser Menggunakan Metode McCall. Yogyakarta: Skripsi Teknik Informatika, UIN Sunan Kalijaga.

[9] Hidayati, A. M. (2014). Verifikasi dan Validasi Kerangka Kerja Pengujian Perangkat Lunak Berbasis McCall's Software Quality Checklist. Yogyakarta: Skripsi Teknik Informatika, UIN Sunan Kalijaga.

[10]IEEE. (1990). Standard Glosary Of Software Engineering Technology.

[11] Millah, N. (2015). Pengujian Faktor Correctness Dan Usability Sistem Informasi Kepegawaian UIN Sunan Kalijaga Yogyakarta Menggunakan Metode MCCALL. Yogyakarta: Skripsi Teknik Informatika, UIN Sunan Kalijaga.

[12] Myers, G. J. (1979). The Art Of Software Testing. Willey.

[13] Notoatmodjo, S. (2005). Metode Penelitian Kesehatan. Jakarta: PT Rineka Cipta.

[14] Nuryanto, A. (2014). Analisis Pengujian Faktor Reliability Sistem Informasi Akademik UIN Sunan Kalijaga Menggunakan Metode Mccall. Yogyakarta: Skripsi Teknik Informatika, UIN Sunan Kalijaga.
[15] Pressman, R. S. (2005). Software Engineering A Practicioner's Approach. Amerika Serikat: Mc Graw Hill.

[16] Rofi'ah, H. (2015). Analisis Pengujian Faktor Reability Sistem Informasi Akademik STMIK El Rahma Yogyakarta Menggunakan Metode MCCALL. Yogyakarta: Skripsi Teknik Informatika, UIN Sunan Kalijaga.

[17] Santosa, P. B. (2005). Analisis Statistik dengan Microsoft Excel dan SPSS. Yogyakarta: Andi.

[18] Septiani, S. (2015). Analisis Usablity Sistem Perpustakaan Kota Yogyakarta Menggunakan Metode MCCALL. Yogyakarta: Skripsi Teknik Informatika, UIN Sunan Kalijaga.

[19] Syafirah, N. E. (2015). Pengujian Faktor Reliability Sistem Informasi Surat UIN Sunan Kalijaga Dengan Menggunakan Teori Mccall. Yogyakarta: Skripsi Teknik Informatika, UIN Sunan Kalijaga.

[20] Utami, P. S. (2015). Analisis Faktor Usabilitas Pada Sistem Informasi Portan Web Pondok Pesantren Ibnul Qoyyim Yogyakarta Berdasarkan McCal's Quality Factor. Yogyakarta: Skripsi Teknik Informatika, UIN Sunan Kalijaga.

[21] Wardani, D. O. (2014). Analisis Perangkat Lunak Opengov Paperless Government Collaboration Suite Pada Pemerintahan Daerah Purbalingga Berdasarkan Teori Kualitas Mccall's. Yogyakarta: Skripsi Teknik Informatika, UIN Sunan Kalijaga.

[22] Yunitasari, Y. (2015). Pengujian Faktor Correctness Dan Usability Sistem E-learning UIN Sunan Kalijaga Yogyakarta Berdasarkan Metode Mccall. Yogyakarta: Skripsi Teknik Informatika, UIN Sunan Kalijaga.

[23]Zakiyah, K. (2015). Analisis Faktor Efisiensi Dan Usabilitas Pada Sistem Admisi UIN Sunan Kalijaga Yogyakarta Berdasarkan Teori Kualitas MCCALL. Yogyakarta: Skripsi Telnik Informatika, UIN Sunan Kalijaga. 